UDC 546.87.22/24.15

\title{
PHYSICO-CHEMICAL INTERACTION IN THE BiSI-BiTeI SYSTEM
}

\author{
E.J.Ahmadov \\ Institute of Catalysis and Inorganic Chemistry, NAS of Azerbaijan \\ elvin.ehmedov.2014@mail.ru
}

Received 21.07.2019

Accepted 23.10.2019

\begin{abstract}
Based on the results of the DTA and X-ray phase analysis, the phase equilibria in the BiTeI-BiSI system were studied and the $T-x$ phase diagram was constructed. It was established that the system is stable in the subsolidus area and there are $\sim 7-8 \mathrm{~mol} \%$ and $\sim 5 \mathrm{~mol} \%$ solid solution areas based on BiTeI and BiSI compounds at room temperature, accordingly. In2016 general, the system is nonquasibinary. $\mathrm{Bi}_{19} \mathrm{~S}_{27} \mathrm{I}_{3}(0-33 \mathrm{~mol} \% \mathrm{BiTeI})$ and tetradymite- $\mathrm{Bi}_{2} \mathrm{Te}_{2} \mathrm{~S}$ (33-83mol\% BiTeI ) phases primarily crystallize from the liquid phase in the wide composition ranges.
\end{abstract}

Keywords: BiTeI-BiSI system, phase diagram, solid solutions, Rashba semiconductors.

doi

\section{Introduction}

Due to their unique properties, $\mathrm{B}^{\mathrm{V}} \mathrm{XHal}$ $\left(\mathrm{B}^{\mathrm{V}}-\mathrm{As}, \mathrm{Sb}, \mathrm{Bi} ; \mathrm{X}-\mathrm{S}, \mathrm{Se}, \mathrm{Te} ; \mathrm{Hal}-\mathrm{Cl}, \mathrm{Br}, \mathrm{I}\right)$ type compounds have been in the center of the researchers' attention from the middle of the last century [1-3]. These compounds exhibit ferroelectric, thermoelectric, photovoltaic, magnetic, optical etc. properties and are considered a promising material for solar-powered devices [4-12]. In recent years, the topological insulator properties and 3D Rashba spin splitting have been observed in these compounds [13-17], that made these alloys even more attractive.

The phase equilibria in $\mathrm{B}^{\mathrm{V}}-\mathrm{X}-\mathrm{Hal}$ systems were studied, the projection of liquidus surfaces was constructed, melting character and primary crystallization regions of existing phases were determined [18-23].

Obtention of phases of variable compositions on basis of the $\mathrm{B}^{\mathrm{V}} \mathrm{XHal}$ type compounds is of great importance to find materials with superior functional properties. The BiTeI-BiSeI and BiTeI-SbTeI systems which are interesting in this regard, have been studied by authors $[24,25]$ and a wide range of solid solutions based on the Rashba semiconductor BiTeI have been detected. Hence, the purpose of the present contribution is to investigate the equilibria in the BiTeIBiSI system and to search for new phases.

Initial compounds of the BiTeI-BiSI system have been studied in detail. BiTeI melts congruently at $828 \mathrm{~K}$ [26]. It has a hexagonal struc- ture with lattice parameters: $a=4.3392$ (1), $c=$ 6.854 (1) $\AA, z=1$ [27]. BiSI melts incongruently by decomposition at $808 \mathrm{~K}$ [28] along the quasi binary $\mathrm{Bi}_{2} \mathrm{~S}_{3}-\mathrm{BiI}_{3}$ system. This compound has orthorhombic crystal structure with: $a=8519$ (5), $b=10177$ (8), $c=4172$ (6) $\AA, z=4$ [29].

\section{Experiments and analyses}

The syntheses of the initial BiTeI and BiSI compounds were carried out by co-melting the stoichiometric proportions of high purity ( $99.999 \%$ by weight) elements in an inclined two-zone furnace under vacuum condition $\left(10^{-2}\right.$ $\mathrm{Pa})$. Initially, the temperature of the "hot" zone was $900 \mathrm{~K}$, whereas the "cold" zone temperature kept at $400 \mathrm{~K}$ (the sublimation temperature of iodine is $386 \mathrm{~K}$ ) considering the high vapor pressure of iodine. After much of the iodine was reacted, the ampoule moved to the "hot" zone. After stirring the homogeneous liquid in the ampoule at this temperature, the furnace cooled gradually. At the next stage, the incongruently melting BiSI compound was annealed at $750 \mathrm{~K}$ for $300 \mathrm{~h}$ and the congruently melting BiTeI was annealed at $780 \mathrm{~K}$ for $20 \mathrm{~h}$, to achieve complete homogenization.

Two sets of samples of different composition ( $0.5 \mathrm{~g}$ each) of the BiTeI-BiSI system were synthesized in evacuated quartz ampoules using initially prepared and identified compounds and annealed at $700 \mathrm{~K}$ for 2 weeks. Experimental studies were conducted by differential-thermal analysis (DTA) and X-ray phase analysis (XRD). 
The DTA was carried out using the differentialscanning calorimeter "NETZSCH 404 F1 Pegasus system" (speed of heating $10 \mathrm{~K} / \mathrm{min}$ ), and XRDin the Bruker $\mathrm{D} 8$ diffractometer $\left(\mathrm{Cu} K_{\alpha}\right.$-radiation) at the $2 \theta=5^{0}-75^{\circ}$ range.

\section{Discussion of the experimental results}

Figure 1 represents the powder X-ray diffraction patterns of thermally treated alloys. As can be seen, the diffraction pattern of the 90 mol\% BiSI sample consists mainly of the BiSI diffraction peaks. The lines of the most intense peaks of the solid solutions based on BiTeI are also observed $\left(12.8,26.9,35.5\right.$ and $\left.46.3^{\circ}\right)$. Similarly, the diffraction pattern of the 10 mol\% BiSI sample consists mainly of the BiTeI diffraction peaks and lines of the most intense peaks $\left(18,20.1,22.5\right.$ and $\left.28.5^{\circ}\right)$ of the solid solutions based on BiTeI. From this result, we can predict that the solubility regions based on BiTeI and BiSI are $\sim 7-8$ and $5 \mathrm{~mol} \%$ respectively. The powder X-ray diffractograms of the 10-90 mol\% BiSI-containing samples consist of peaks of both mutually saturated solid solutions.

$T-x$ phase diagram of the system was constructed using DTA results (Table 1). The system is non-quasibinary due to the peritectic melting character of BiSI. However, it is stable in subsolidus and characterized by the for- mation of limited solid solutions on the basis of initial compounds (Figure 2).

Liquidus consists of three curves. Based on $T-x$ diagrams of the $\mathrm{Bi}_{2} \mathrm{~S}_{3}-\mathrm{BiI}_{3}$ [18] and $\mathrm{Bi}_{2} \mathrm{Te}_{3}-\mathrm{BiI}_{3}$ [19] systems, we can assume that $\varepsilon$ (based on $\mathrm{Bi}_{19} \mathrm{~S}_{27} \mathrm{I}_{3}$ ), $\delta$ (based on $\mathrm{Bi}_{2} \mathrm{Te}_{2} \mathrm{~S}$ ) and $\gamma_{2}$ (based on BiTeI) phases crystallize in the 0 $33 \mathrm{~mol} \%$ BiTeI, 33-83 mol\% BiTeI and >83 mol\% composition interval, respectively. Crystallization in the L+E field continues with monovariant $\mathrm{L}+\varepsilon \leftrightarrow \gamma_{1}$ peritectic ( $\mathrm{PU}_{1}$ curve) and $\mathrm{L} \leftrightarrow \varepsilon+\gamma_{2}$ eutectic (15-40 mol\% BiTeI) reactions. The horizontal line at $775 \mathrm{~K}$ conforms the transition reaction $\left(\mathrm{U}_{1}\right)$ :

$$
\mathrm{L}+\varepsilon \leftrightarrow \delta+\gamma_{1}
$$

Crystallization in the $40-53 \mathrm{~mol} \%$ BiTeI composition intervals continues with monovariant $\mathrm{L} \leftrightarrow \gamma_{1}+\delta$ and in the $53-83 \mathrm{~mol} \%$ BiTeI composition intervals - with eutectic $\mathrm{L} \leftrightarrow \gamma_{2}+\delta$ reactions. At about $8-83$ mol\% BiTeI composition interval crystallization ends by the transition reaction $\left(\mathrm{U}_{2}\right)$ (Figure 2$)$ :

$$
\mathrm{L}+\delta \leftrightarrow \gamma_{1}+\gamma_{2} .
$$

At the transition reaction temperature, the homogeneity area of the $\gamma_{1}$ phase is $\sim 7 \mathrm{~mol} \%$, and the homogeneity area of the $\gamma_{2}$ phase is $\sim 13$ mol\%.

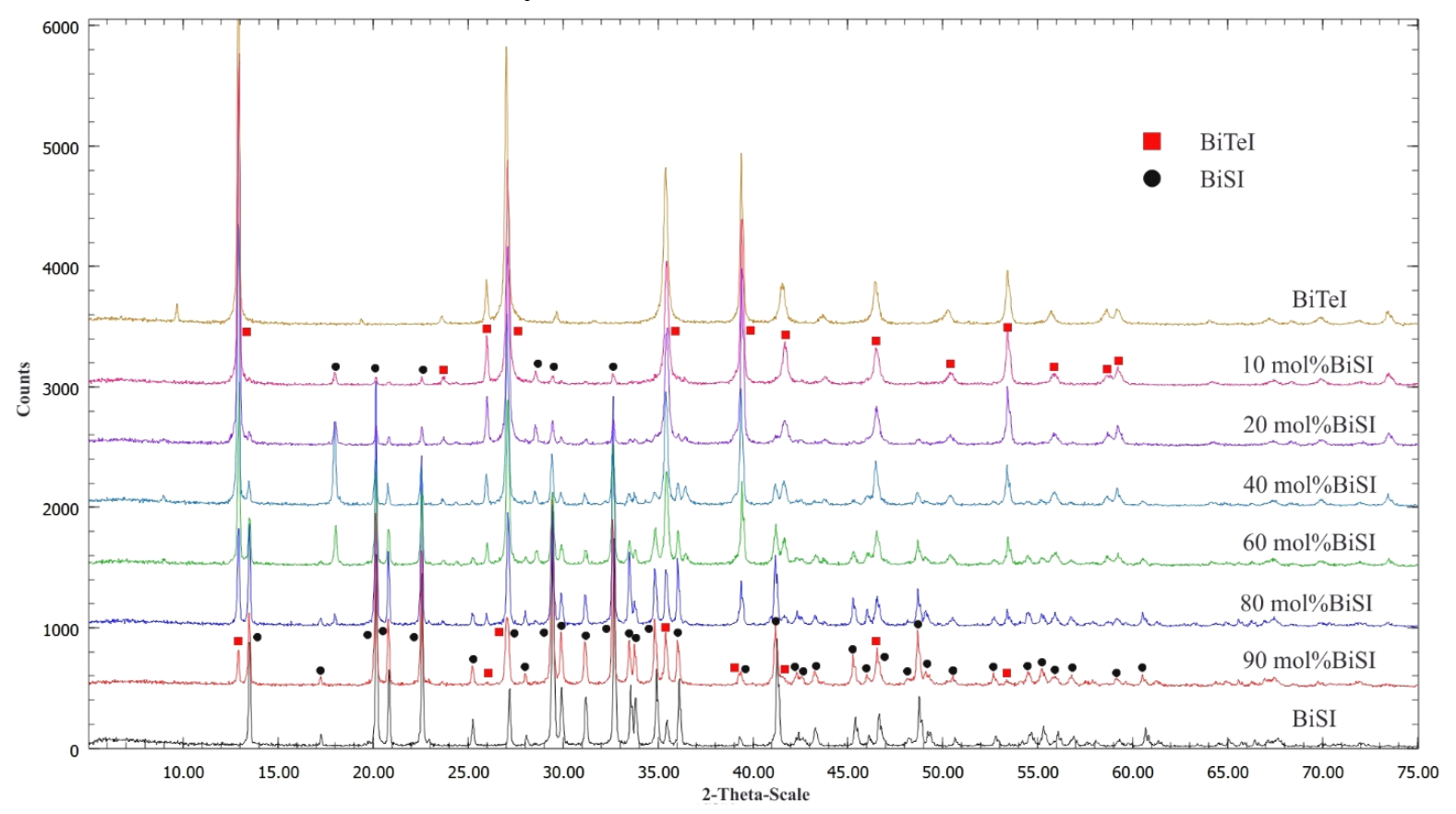

Fig. 1. X-ray images of some alloys of the BiTeI-BiSI system. 


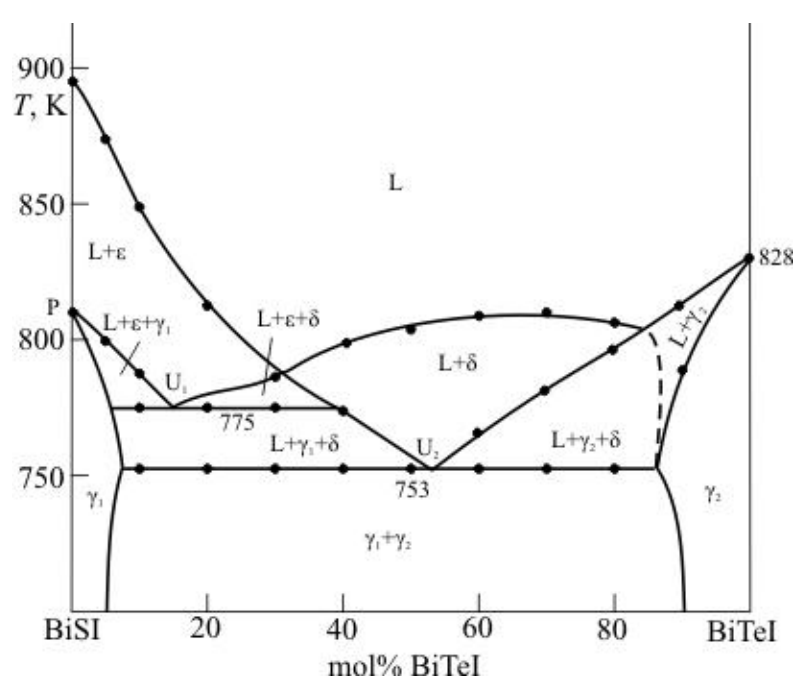

DTA results for the system BiTeI-BiSI

\begin{tabular}{|c|c|}
\hline Composition, mol\% BiTeI & Thermal effects, $K$ \\
\hline 0 (BiSI) & $808 ; 895$ \\
\hline 5 & $780-800-873$ \\
\hline 10 & $753 ; 775-788-848$ \\
\hline 15 & $753 ; 775-828$ \\
\hline 20 & $753 ; 775-780-811$ \\
\hline 25 & $753 ; 775-782-801$ \\
\hline 30 & $753 ; 775-785-791$ \\
\hline 40 & $753 ; 775-798$ \\
\hline 50 & $733 ; 758-805$ \\
\hline 60 & $753 ; 766-809$ \\
\hline 70 & $753 ; 782-810$ \\
\hline 80 & $753 ; 796-806$ \\
\hline 90 & $788-813$ \\
\hline $100($ BiTeI) & 828 \\
\hline
\end{tabular}

Fig. 2. Phase diagram of the BiTeI-BiSI system.

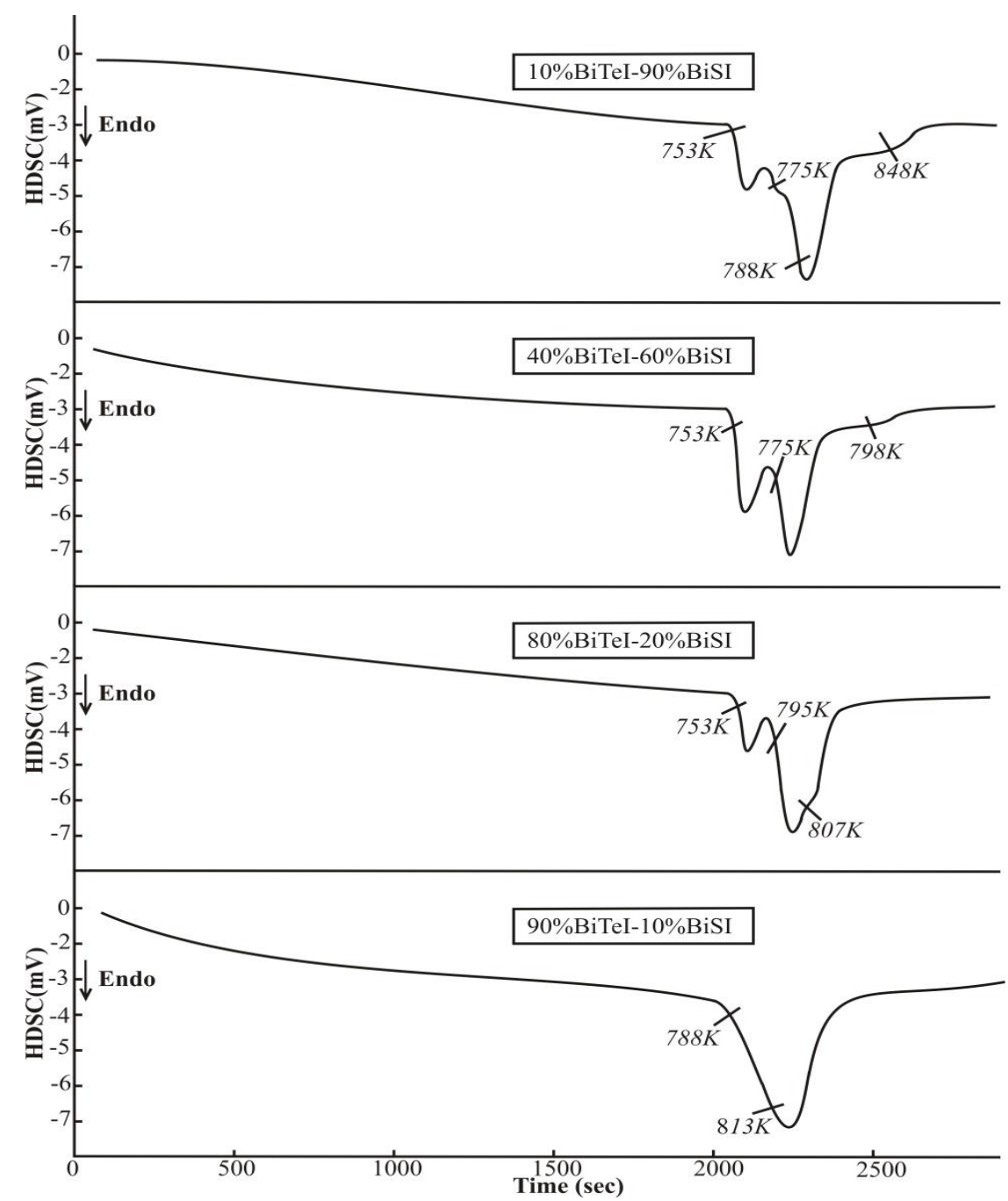

Fig. 3. DTA curves of some alloys of the system BiTeI-BiSI. 
Let us explain the phase diagram (Figure 2 ) in the context of heating curves (Figure 3 ) of some alloys in the BiTeI-SbTeI system. As it can be seen, a diffused endo effect is observed in the heating thermogram of $90 \mathrm{~mol} \%$ BiTeI containing sample. This reflects the melting of the $\gamma_{2}$ phase based on BiTeI at 788-813 K. The strong endo effect observed at $753 \mathrm{~K}$ in a sample of $80 \mathrm{~mol} \% \mathrm{BiTeI}$ is appropriate to the $\mathrm{U}_{2}$ transition reaction, subsequent thermal effects reflect the monovariant eutectic $L \leftrightarrow \gamma_{2}+\delta$ process and the end of melting. On the thermogram of $40 \mathrm{~mol} \%$ BiTeI containing sample, the sharp peak at $753 \mathrm{~K}$ represents $\mathrm{U}_{2}$ transition reaction, while the peaks at $775 \mathrm{~K}$ and $798 \mathrm{~K}$ belong to the melting of $\mathrm{L}+\gamma_{1}+\delta$ and $\mathrm{L}+\delta$ eutectic mixtures, accordingly. Similarly, in $10 \mathrm{~mol} \% \mathrm{BiTeI}$ containing sample the intensive peaks at $753 \mathrm{~K}$ and $775 \mathrm{~K}$ belong to $\mathrm{U}_{2}$ and $\mathrm{U}_{1}$ transition reactions, and the peaks at $788 \mathrm{~K}$ and $848 \mathrm{~K}$ demonstrate the melting of $L+\varepsilon+\gamma_{1}$ and $L+\varepsilon$ eutectic mixtures.

\section{Conclusion}

For the first time, the existence of $\mathrm{BiTe}_{1-}$ ${ }_{x} S_{x} I$ solid solutions was detected using DTA and XRD methods and the phase diagram of the system was constructed. It was established that, although the system is non-quasibinary, it is stable in subsolidus and is characterized by the formation of limited solid solutions on the of basis initial compounds. Maximum solubility was observed at $750 \mathrm{~K}: \sim 6 \mathrm{~mol} \%$ on the basis of BiSI and more than $\sim 10 \mathrm{~mol} \%$ based on BiTeI. New solid solutions based on the BiTeI are of great practical interest as potential Rashba semiconductors and topological insulator materials.

\section{References}

1. Fenner J., Rabenau A., Trageser G. Solid-state chemistry of thio Seleno and tellurohalides of representative and transition elements. Adv. Inor. Radiochemistry 1980. V. 23. P. 329-416.

2. Oppermann H., Petasch U. The Pseudobinary Systems $\mathrm{Bi}_{2} \mathrm{Ch}_{3}-\mathrm{BiX}_{3}$ and the Ternary Phases on their Boundary Lines $(\mathrm{Ch}=\mathrm{S}$, Se, Te; $\mathrm{X}=\mathrm{Cl}, \mathrm{Br}, \mathrm{I}), \mathrm{I}$ : Bismuth Sulfide Halides. Z. Naturforsch. 2003. V. 58. P. 725-740.

3. Gerzanich and Fridkin V. M. Ferroelectrics of the $\mathrm{A}^{\mathrm{V}} \mathrm{B}^{\mathrm{VI}} \mathrm{C}^{\mathrm{VII}}$ Type. M.: Nauka. 1982. P. 114.
4. Koc H., Palaz S., Mamedov A.M., Ozbay E. Optical, electronic, and elastic properties of some $\mathrm{A}^{5} \mathrm{~B}^{6} \mathrm{C}^{7}$ ferroelectrics $(\mathrm{A}=\mathrm{Sb}, \mathrm{Bi} ; \mathrm{B}=\mathrm{Te}, \mathrm{S}, \mathrm{Se}$; $\mathrm{C}=\mathrm{I}, \mathrm{Br}, \mathrm{Cl})$ : First principle calculation. Ferroelectrics. 2017. V. 511. P. 22-34.

5. Khan W., Hussain S., Minar J. and Azam S. Electronic and Thermoelectric Properties of Ternary Chalcohalide Semiconductors: First Principles Study. J. Elec. Materials. 2017. V. 47. No 2. P. 1131-1139.

6. Guo S.D. and Zhang A.X. Potential 2D thermoelectric materials ATeI ( $\mathrm{A}=\mathrm{Sb}$ and $\mathrm{Bi})$ monolayers from a first-principles study. Mat. Sci. Condensed Matter. 2017. V. 28. No 44. P. 1-8.

7. Ganose A.M., Butler K.T., Walsh A., Scanlon D.O. Relativistic electronic structure and band alignment of BiSI and BiSeI: candidate photovoltaic materials. J. Mat. Chem. 2016. V. 4. No 6. P. 2060-2068.

8. Ozer T., Cabuk S. First-principles study of the structural, elastic and electronic properties of SbXI (X=S, Se, Te) crystals. J. Mol. Model. 2018. V. 24. No 3. P. 1-9.

9. Demko L., Schober G.A.H., Kocsis V., Bahramy M.S., Murakawa H., Lee J.S., Kezsmarki I., Arita R., Nagaosa N., Tokura Y. Giant magneto-optical response in non-magnetic semiconductor BiTeI driven by bulk Rashba spin splitting. Phys. Rew. Letter. 2012. V. 109. No 16. P. 1-5.

10. Ran Z., Wang X., Li Y., Yang D., Zhao X.G., Biswas K., Singh D.J., Zhang L. Bismuth and Antimony Based Oxyhalides and Chalcohalides as Potential Optoelectronic Materials. Comput. Mater. 2018. V. 4. No 14. P. 1-33.

11. Audzijonis A., Zaltauskas R., Sereikan R., Zigas L., Reza A. Electronic structure and optical properties of BiSI crystal. J. Phys. Chem. Solids. 2010. V. 71. P. 884-891.

12. Ganose A.M., Matsumoto S., Buckeridge J., Scanlon D.O. Defect Engineering of EarthAbundant Solar Absorbers BiSI and BiSeI. Chem. Mater. 2018. V. 30. P. 3827-3835.

13. Bahramy M.S., Yang B.J., Arita R., Nagaosa N. Emergence of non-centrosymmetric topological insulating phase in BiTeI under pressure. Nat. Com., 2012. V. 3. No 1. P. 1-7.

14. Babanly M.B., Chulkov E.V., Aliev Z.S., Shevelkov A.V., Amiraslanov I.R. Phase Diagrams in Materials Science of Topological Insulators Based on Metal Chalcogenides. Rus. J. I. Chem. 2017. V. 62. No 13. P. 1703-1729.

15. Wu L., Yang J., Zhang T., Wang S., Wei P., Zhang W., Chen L., Yang J. Enhanced thermoelectric performance in the Rashba semiconductor BiTeI through band gap engineering. J. Physics: Conden. Matter. 2016. V. 28. No 8. P. 1-7.

16. Landolt G., Eremeev S.V., Koroteev Y.M., Slomski B., Muff S., Neupert T., Kobayashi M., Strocov V.N., Schmitt T., Aliev Z.S., Babanly 
M.B., Amiraslanov I.R., Chulkov E.V., Osterwalder J. and Dil J.H. Disentanglement of Surface and Bulk Rashba Spin Splittings in Noncentrosymmetric BiTeI. Rew. Phys. Rev. Letters. 2012. V. 109. No 11. P. 1-5.

17. Ishizaka K., Bahramy M.S., Murakawa H., Sakano M., Shimojima T., Sonobe T., Koizumi K., Shin S., Miyahara H., Kimura A., Miyamoto K., Okuda T., Namatame H., Taniguchi M., Arita R., Nagaosa N., Kobayashi K., Murakami Y., Kumai R., Kaneko Y., Onose Y. and Tokura Y. Giant Rashba-type spin splitting in bulk BiTeI. Nat. Mater. 2011. V. 10. No 7. P. 521-526.

18. Aliev Z.S., Musaeva S.S., Jafarli F.Y., Amiraslanov I.R., Shevelkov A.V., Babanly M.B. The phase equilibria in the Bi-S-I ternary system and thermodynamic properties of the BiSI and $\mathrm{Bi}_{19} \mathrm{~S}_{27} \mathrm{I}_{3}$ ternary compounds. J. Alloys and Compounds. 2014. V. 610. P. 522-528.

19. Babanly M.B., Tedenac J.C., Aliev Z.S., Balitsky D.M. Phase eqilibriums and thermodynamic properties of the system Bi-Te-I. J. Alloys and Compounds. 2009. V. 481. No 1-2. P. 349-353.

20. Aliev Z.S. Synthesis and characterization of the $\mathrm{BiTe}_{1-\mathrm{x}} \mathrm{Se}_{\mathrm{x}} \mathrm{I}$ solid solutions series. Az. J. Physics. V. 25. No 2. P. 37-40.

21. Aliev Z.S., Musaeva S.S., Babanly D.M., Shevelkov A.V., Babanly M.B. Phase diagram of the $\mathrm{Sb}-\mathrm{Se}-\mathrm{I}$ system and thermodynamic properties of SbSeI. J. Alloys and Compounds. 2010. V. 505. P. 450-455.

22. Aliev Z.S., Babanly D.M., Babanly M.B., Shevelkov A.V., Amiraslanov I.R. Phase diagram and thermodynamic properties of the system AsTeI. J. Alloys and Compounds. 2011. V. 509. P. 602608.

23. Aliev Z.S., Babanly M.B., Shevelkov A.V., Babanly D.M., Tedenac J.C. Phase diagram of the $\mathrm{Sb}-\mathrm{Te}-\mathrm{I}$ system and thermodynamic properties of SbTeI. Int. J. Mate. Res. 2012. V. 103. No 3. P. 290-295.

24. Aliev Z.S., Ahmadov E.C., Babanly D.M., Amiraslanov I.R., Babanly M.B. The $\mathrm{Bi}_{2} \mathrm{Se}_{3}-$ $\mathrm{Bi}_{2} \mathrm{Te}_{3}-\mathrm{BiI}_{3}$ system: Synthesis and characterization of the $\mathrm{BiTe}_{1-\mathrm{x}} \mathrm{Se}_{\mathrm{x}} \mathrm{I}$ solid solutions. Calphad. 2019. V. 66. P. 101650-101655.

25. Ahmadov E.J., Babanly D.M., Aliyev Z.S., Zlomanov V.P. Phase equilibria in the system SbTeIBiTeI. New. Mat. Comp. Applications. 2019. V. 3. No 2. P. 87-93.

26. Tomokiyo A., Okada T., Kawano S. Phase Diagram of System (Bi2Te3)-(BiI3) and Crystal Structure of BiTeI. J. J. App. Physics. 1977. V. 16. No 2. P. 291-298.

27. Shevelkov A.V., Dikarev E.V., Shpanchenko R.V., Popovkin B.A. Crystal Structures of Bismuth Tellurohalides $\operatorname{BiTe} X(X=\mathrm{Cl}, \mathrm{Br}, \mathrm{I})$ from $\mathrm{X}$ Ray Powder Diffraction Data. J. Solid State Chemistry. 1995. V. 114. No 2. P. 379-384.

28. Ryazantsev T.A., Varekha L.M., Popovkin B.A., Novoselova A.V. Inorg. Materials. 1970. V. 6. P. $1175-1179$.

29. Haase-Wessel W. Die Kristal struktures of Wismut sulfid jodids (BiSJ). Naturwissenschaften. 1973. V. 60. P. 474.

\section{BiSI-BiTeI SISTEMINDə FİIKİ-KIMMYəVİ QARŞILIQLI TəSİR E.C.Ohmədov}

DTA və RFA nəticələrinə əsasən BiTeI-BiSI sistemində faza tarazlıqları öyrənilmiş və $T-x$ faza diaqramı qurulmuşdur. Müəyyən olunmuşdur ki, sistem subsolidusda stabildir və otaq temperaturunda BiTeI əsasında 7-8 mol\%, BiSI əsasında isə 5 mol\%-ə yaxın bərk məhlul sahəsi əmələ gətirir. Bütövlükdə isə sistem qeyri-kvazibinardır. Geniş tərkib intervallarında maye fazadan ilkin olaraq $\mathrm{Bi}_{19} \mathrm{~S}_{27} \mathrm{I}_{3}(0-33 \mathrm{~mol} \% \mathrm{BiTeI})$ və tetradimit $-\mathrm{Bi}_{2} \mathrm{Te}_{2} \mathrm{~S}$ (33-83 mol\% BiTeI) kristallaşır.

Açar sözlor: BiTeI-BiSI sistemi, faza diaqramı, bərk məhlullar, Raşba yarımkeçiricilari.

\section{ФИЗИКО-ХИМИЧЕСКОЕ ВЗАИМОДЕЙСТВИЕ В СИСТЕМЕ ВіSI-BiTеI}

\section{Е.Дж.Ахмедов}

На основании результатов ДТА и рентгенофазового анализов были изучены фазовые равновесия в системе BiTeI-BiSI и построена фазовая диаграмма $T-x$. Установлено, что система стабильна в области субсолидуса. На основе соединений BiTeI и BiSI образуются твердые растворы, которые при комнатной температуре занимают области $\sim 7-8$ и $\sim 5$ мол\% соответственно. Однако в общем система - неквазибинарная. В широком диапазоне составов из жидкости кристаллизуются $\mathrm{Bi}_{19} \mathrm{~S}_{27} \mathrm{I}_{3}$ (0-33 мол\% $\mathrm{BiTeI}$ ) и тетрадимит- $\mathrm{Bi}_{2} \mathrm{Te}_{2} \mathrm{~S}$ (33-83моль\% $\mathrm{BiTeI}$ ).

Ключевые слова: система BiTeI-BiSI, фазовая диаграмма, твердые растворы, полупроводники Рашбы. 